\title{
Desert dust hazards: A global review
}

2

\section{$3 \quad$ Highlights}

\section{Abstract}

-Discusses distribution and frequency of dust storms across the world.

-Discusses long-distance transport pathways.

-Examines the effects of desert dust storms on human society.

-Reviews economic assessments of desert dust hazards.

Dust storms originate in many of the world's drylands and frequently present hazards to human society, both within the drylands themselves but also outside drylands due to long-range transport of aeolian sediments. Major sources of desert dust include the Sahara, the Middle East, central and eastern Asia, and parts of Australia, but dust-raising occurs all across the global drylands and, on occasion, beyond. Dust storms occur throughout the year and they vary in frequency and intensity over a number of timescales. Long-range transport of desert dust typically takes place along seasonal transport paths. Desert dust hazards are here reviewed according to the three phases of the wind erosion system: where dust is entrained, during the transport phase, and on deposition. This paper presents a synthesis of these hazards. It draws on empirical examples in physical geography, medical geology and geomorphology to discuss case studies from all over the world and in various fields. These include accelerated soil erosion in agricultural zones - where dust storms represent a severe form of accelerated soil erosion - the health effects of air pollution caused by desert aerosols via their physical, chemical and biological properties, transport accidents caused by poor visibility during desert dust events, and impacts on electricity generation and distribution. Given the importance of desert dust as a hazard to human societies, it is surprising to note that there have been relatively few attempts to assess their impact in economic terms. Existing studies in this regard are also reviewed, but the wide range of impacts discussed in this paper indicates that desert dust storms deserve more attention in this respect.

Keywords: Desert dust; Mineral aerosols; Particulate matter; Drylands; Climate hazards; Wind erosion

\section{Acknowledgements}

This paper benefitted from comments made by two anonymous reviewers. 


\section{Introduction}

Dust storms, most of which originate in the world's deserts and semi-deserts - commonly referred to as drylands - play an integral role in the Earth system (Goudie and Middleton, 2006; Shao et al., 2011). Their impacts are numerous and wide-ranging, including effects on climate processes and air chemistry, nutrient dynamics and biogeochemical cycling in both oceanic and terrestrial environments, soil characteristics and geomorphology. All of these impacts have repercussions for human society, of course, but people are also influenced more directly by a number of desert dust hazards, such as atmospheric pollution. Given that drylands cover about $40 \%$ of the world's land surface and are home to more than 2 billion people (Safriel et al., 2005), these hazards are of considerable importance, but their significance is further magnified because desert dust events frequently involve long-range transport over thousands of kilometres, often taking dust far beyond dryland environments.

Our understanding of desert dust and our appreciation of its significance in the Earth system has increased markedly in recent years. In large part, this has been driven by self-interest due to the direct and indirect effects dust can have on human society. Indeed, over the last 100 years or so pulses of aeolian research output have occurred in response to major ecological disasters that have focused attention on wind erosion and blowing dust (Stout et al., 2009). We know that dust emissions vary in frequency and intensity seasonally and over longer timescales (Goudie and Middleton, 1992), responding to droughts (Middleton, 1985) and large-scale standing atmospheric pressure oscillations such as the North Atlantic Oscillation (Moulin et al., 1997), but the recent increase in dust storms in some areas (e.g. Kim, 2008; Ganor et al., 2010; Ghasem et al., 2012; Hsu et al., 2012; Notaro et al., 2015) prompted the United Nations General Assembly (UNGA) to adopt a resolution in 2015 entitled "Combatting sand and dust storms" (A/RES/70/195). This was followed in 2016 by the second UN Environment Assembly (UNEA-2) adopting a resolution that requests countries to address the challenges of sand and dust storms through relevant policy measures.

The purpose of this paper is to review the ways in which desert dust is related to hazardous conditions experienced by human populations both within drylands and beyond their margins. This synthesis of hazards research follows a brief resumé of our knowledge on the nature of desert dust storms, particularly their main sources areas, frequencies and long-distance transport pathways.

\section{Desert dust}

There are numerous sources of tropospheric aerosols, including sea salt, volcanic dust, cosmic dust and industrial pollutants, but this paper refers to mineral dust that originates from land surfaces. Most of this material comes from desert and semi-desert areas and is therefore commonly referred to as desert dust. Dust storms are atmospheric events typically associated with drylands because of the preponderance of desiccated, unconsolidated substrates with little vegetation cover. Strong, turbulent winds blowing over desert surfaces raise fine-grained material, much of it consisting of silt-sized (4$62.5 \mu \mathrm{m})$ and clay-sized $(<4 \mu \mathrm{m})$ particles, to reduce visibility to less than $1 \mathrm{~km}$ (Figure 1 ).

Atmospheric $\mathrm{PM}_{10}$ dust concentrations exceed 15,000 $\mu \mathrm{g} / \mathrm{m}^{3}$ in severe events (Leys et al., 2011), although concentrations naturally diminish with distance from source areas as material in suspension is deposited downwind by wet and dry processes. Desert dust is dominated by $\mathrm{SiO}_{2}$ and $\mathrm{Al}_{2} \mathrm{O}_{3}$, but may also contain significant proportions of $\mathrm{Fe}_{2} \mathrm{O}_{3}, \mathrm{CaO}$ and $\mathrm{MgO}$. Many desert dust source areas also contribute a large salt content, organics content, pathogens and anthropogenic pollutants. 


\section{Figure 1. Sydney harbour bridge obscured by thick dust during the notorious Red Dawn event in Australia in September 2009 (Photo: Mrcricket48)}

\subsection{Source areas}

Not all drylands are equally active from a dust storm perspective. Analyses of data from terrestrial meteorological stations and a number of satellite borne sensors has provided us with a decent, though not perfect, understanding of where the planet's major contemporary desert dust sources are located (Ginoux et al., 2012; Washington et al., 2003), although these surveys omit most high-latitude sources (Bullard, et al. 2016). The Sahara is undoubtedly the largest source of atmospheric desert dust, contributing perhaps $50 \%$ of the global total, followed by China and Central Asia (about 20\% of the global total), Arabia and Australia. Drylands in Southern Africa and the Americas are relatively minor sources, together accounting for probably less than $5 \%$ of the global total. These regional proportions are by necessity tentative because quantifying the global mineral dust mass budget is not a straightforward matter. Since actual measurements are geographically sparse and temporally sporadic, the majority of estimates are produced using models. Most estimates of total mineral dust emissions to the global atmosphere range between one billion and three billion tonnes per annum (e.g. Mahowald et al., 1999; Miller et al., 2004). The lack of agreement between models is largely a reflection of the fact that there remains much to learn about dust emission and transport processes (Cakmur et al., 2006; Evan et al., 2014).

Within dryland regions, certain types of geomorphology are typically richer in dust-sized material than others (Bullard et al., 2011). Water plays a particularly important role in providing dust-producing desert surfaces such as large basins of internal drainage (e.g. Bodélé, Taoudenni, Seistan, Eyre), alluvial deposits, playas and piedmont alluvial fans. These and a number of other typically abundant sources of desert dust are shown with regional examples in Table 1. Dust is deflated from these sources with a marked seasonality. The Bodélé Depression produces most of its dust during a season lasting from October to April, affecting much of West Africa with the Harmattan dust haze. In the Middle East, southern Iraq, Kuwait, southern Iran and the eastern coast of the Arabian Peninsula are affected by the Shamal, a northwesterly dust-bearing wind that typically prevails between February and October. 
Table 1. Geomorphological units from which substantial dust deflation occurs

\begin{tabular}{|l|r|r|}
\hline Geomorphological unit & Regional example & \multicolumn{1}{c|}{ Reference } \\
\hline Floodplain & Lower Mesopotamia, Iraq & Al-Dousari and Al-Awadhi (2012) \\
\hline Dry river bed (wadi) & Patagonia, Argentina & Johnson et al. (2010) \\
\hline Alluvial fan & Hexi Corridor, China & Derbyshire et al. (1998) \\
\hline Salt pan & Mojave Desert, USA & Reynolds et al. (2007) \\
\hline Palaeolake bed & Bodélé Depression, Chad & Bristow et al. (2009) \\
\hline Ephemeral lake bed & Hamoun Basin, Iran/Afghanistan & Rashki et al. (2013) \\
\hline Active dunes & Erg in Koussamene, Mali & Coudé-Gaussen (1989) \\
\hline Devegetated fossil dunes & Lake Eyre Basin, Australia & Bullard et al. (2008) \\
\hline Glacial outwash plain & Sandar plains, southern Iceland & Prospero et al. (2012) \\
\hline Loess & Loess Plateau, China & Park and In (2003) \\
\hline
\end{tabular}

Many dust sources are naturally active (e.g. the world's largest source of desert dust - the Sahara's Bodélé Depression) but elsewhere dust is entrained from environments that have become susceptible to wind action through human influence. These situations include lake beds that have been desiccated due to society's use of water, as in the Aral Sea in Central Asia (Issanova et al., 2015), and agricultural fields left bare after harvests and/or ploughing, as during the notorious Dust Bowl years on the Great Plains of the USA (McLeman et al., 2014). The mismanagement of rangeland is another frequently cited cause (Hoffmann et al., 2008), but the issue of overgrazing is controversial and there are many uncertainties in our understanding of how grasslands may act as dust sources (Shinoda et al., 2011; Middleton, 2016).

Anthropogenic activities may also affect dust emissions indirectly, by changing climate and the hydrological cycle. Climate change is an important potential driver of future wind erosion and dust storm occurrence, especially via the occurrence of more extreme wind events, greater drought frequency and greater aridity in some areas (Dai, 2010; IPCC 2012). The relative contribution to global dust emissions of sources significantly influenced by human action is a subject for debate with estimates varying from 50\% (Tegen et al., 1996) to insignificant (Prospero et al., 2002). This high degree of uncertainty can be attributed in large part to the relative lack of detailed characterization of global dust sources.

\subsection{Long-distance transport}

Numerous studies have demonstrated that desert dust is commonly transported over thousands of kilometres through the troposphere and hence affects geochemical conditions at great distances from dust sources (Figure 2). Saharan dust, for instance, has influenced the nature of soils in the Canary Islands (Menéndez et al., 2007) and on Mount Cameroon (Dia et al., 2006), but its contribution of micro-nutrients to ecosystems has also been detected much further afield: in northern Europe (Franzen et al., 1994), the Caucasus Mountains (Kutuzov et al., 2013), the southwestern USA (Prospero, 1999), on Caribbean islands (Muhs et al., 2007), in the Amazon (Swap et al., 1992) and the Andes (Boy and Wilcke, 2008). Dust from northeast Asian deserts is also frequently transported great distances. In and around the Gobi Desert, much attention has been devoted to hazards associated with long-distance dust transport to major regional cities, including Beijing (Liu et al. 2014), Seoul and Tokyo (Kashima et al. 2016). Material from the Taklamakan Desert is also frequently carried across the Pacific Ocean to the North American continent (McKendry et al., 2001), Greenland (Bory et al., 2003), Europe (Grousset et al., 2003) and on occasion even further (Uno et al., 2009).

The transboundary nature of many dust events represents a considerable challenge to policymakers, although regional cooperation has yielded progress in some parts of the world. Notable examples include the Regional Master Plan for prevention and control of dust and sand storms in northeast Asia, involving the governments of China, Japan, Mongolia and South Korea (UNCCD, 

East and Europe (Terradellas, 2015). There are plans to introduce a Global Dust-Health Early Warning System (Sprigg, 2016).

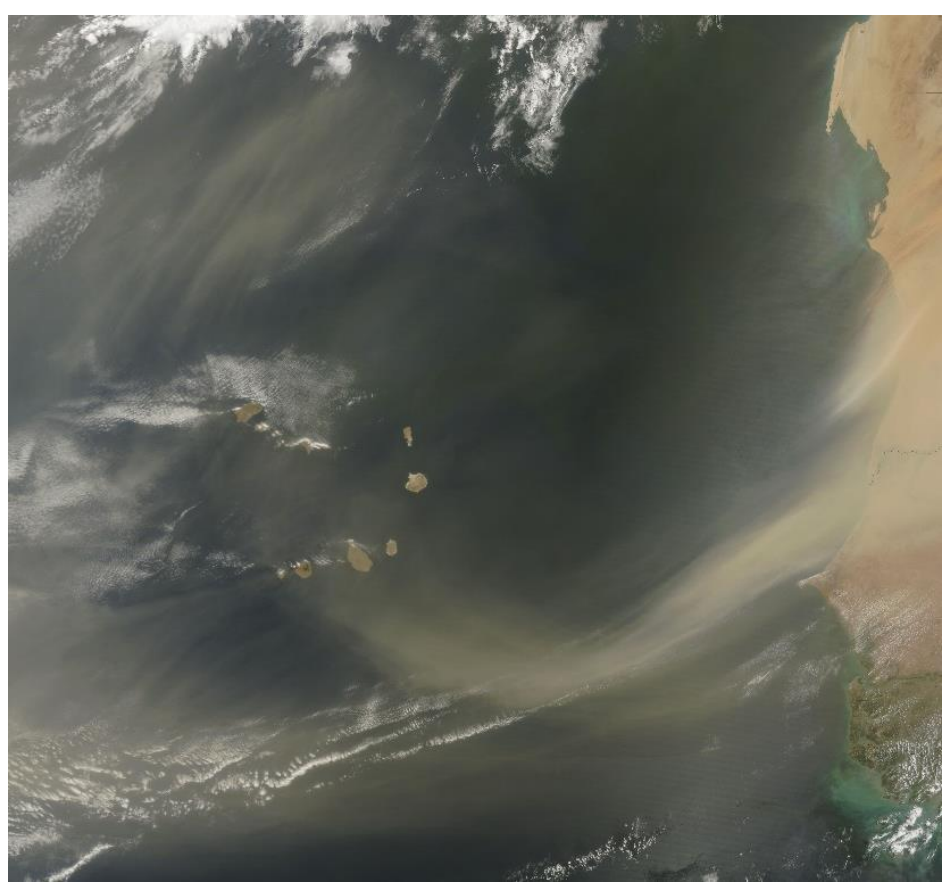

Figure 2. Long-range transport of Saharan dust blowing off the coasts of Mauritania and Senegal over the Atlantic towards Cape Verde (Image: NASA MODIS)

\section{Desert dust hazards}

Dust storms create hazards for human society in numerous ways (Goudie and Middleton, 2006; Middleton and Sternberg, 2013). An attempt to categorise these hazards by the three processes of the wind erosion system is shown in Table 2. Further discussion of some important empirical examples follows from places where dust has been hazardous on entrainment, during the transport phase, and on deposition.

Table 2. Some environmental hazards to human populations caused by wind erosion and dust storms

\begin{tabular}{|l|l|l|}
\hline Entrainment & Transport & Deposition \\
\hline Soil loss & Sand-blasting of crops & $\begin{array}{l}\text { Salt deposition and } \\
\text { groundwater salinization }\end{array}$ \\
\hline $\begin{array}{l}\text { Nutrient, seed and fertilizer } \\
\text { loss }\end{array}$ & Radio communication of reservoir storage \\
\hline Crop root exposure & Microwave attenuation & Drinking-water contamination \\
\hline Undermining structures & Transport disruption & Burial of structures \\
\hline & Local climatic effects & Crop growth problems \\
\hline & Air pollution & Machinery problems \\
\hline & $\begin{array}{l}\text { Respiratory problems and eye } \\
\text { infections }\end{array}$ & $\begin{array}{l}\text { Reduction of solar power } \\
\text { potential }\end{array}$ \\
\hline & Disease transmission (human) & Electrical insulator failure \\
\hline & $\begin{array}{l}\text { Disease transmission (plants \& } \\
\text { animals) }\end{array}$ & Disruption to power supplies \\
\hline
\end{tabular}




\subsection{Entrainment phase}

168 When material is entrained from agricultural fields, a dust storm represents a severe form of accelerated soil erosion (Nordstrom and Hotta, 2004). Wind erosion reduces soil productivity in a variety of ways. Soil particles, nutrients, fertilizers and seeds are lost and the eroded particles may also cause serious damage to crops by abrasion, a problem that is particularly critical for young shoots. Deflation of soils removes the finest particles, which are some of the most important soil constituents: clay, silt and organic matter. Since the ratio of sand, silt and clay sized particles is of primary importance to a soil's stability (Chepil and Woodruff, 1963), the preferential removal of fines is detrimental to soil structure. These particles also have an important influence on a soil's water retention capacity, so their removal reduces soil moisture storage. A soil's nutrients also tend to be attached to the smallest and lightest particles, so that the loss of fines reduces fertility (Zobeck et al., 1989). Overall, the loss of topsoil due to wind erosion readily translates into a measureable effect on crop yields (Larney et al., 1998).

Other effects of deflation include the scouring and undermining of structures such as telegraph poles, fencing, walls, railway sleepers and roads. On occasion such impacts may result in the collapse of structures. In the Afghan region of Seistan, the dust-laden northerly Wind of 120 days is so destructive that local houses are built with dead walls facing the wind (Middleton, 1986).

One of the best-known examples of large-scale wind erosion and dust storm activity anywhere in the world occurred on the Great Plains of the USA during the 1930s. The most severe dust storms ('black blizzards') occurred in the Dust Bowl between 1933 and 1938, with activity being at a maximum during the spring of those years. At Amarillo, Texas, at the height of the period, one month had 23 days with at least ten hours of airborne dust, and one in five storms had zero visibility (Choun, 1936). For comparison, the long-term average for this part of Texas is just six dust storms a year (Changery, 1983).

The drivers of this ecological disaster have been widely discussed, and blame has largely been laid at the feet of pioneering farmers who ploughed up the plains for cultivation. The waves of settlers that arrived in the area from 1914 to 1930, in conjunction with the increasing use of mechanised agriculture, catalysed by high wheat prices, led to exceptionally large-scale wind erosion when drought hit the plains in 1931. In 1937 the US Soil Conservation Service estimated that $43 \%$ of a 6.5 million ha area in the heart of the Dust Bowl had been seriously damaged by wind erosion (Worster, 1979).

Recent studies indicate that the degree of aridity over the Great Plains during the 1930s was unusual. Cook et al. (2014) suggest that in the summer of 1934 over $70 \%$ of western North America experienced extreme drought, making 1934 the single worst drought year of the last millennium. However, this is not to exonerate the human impact, since analysis using general circulation models (GCMs) indicates that human-induced land degradation (reduced vegetation cover and large-scale emissions of soil dust, both consequences of crop failure) are likely to have suppressed precipitation during the Dust Bowl and may have amplified the drying in 1934 (Cook et al., 2009). Irrespective of the relative importance of anthropogenic and natural drivers, the Dust Bowl disaster was undoubtedly exacerbated by the severe economic problems that affected North America during the 1930s (Lee and Gill, 2015), which made it very difficult for farmers adequately to deal with this environmental catastrophe.

Similar widespread deflation of soils resulted from analogous expansion of cultivation into grasslands in the Argentine Pampas during the 1930s and 1940s (Viglizzo and Frank, 2006) and after the 1950s Virgin Lands Scheme in the former USSR (Indoitu et al., 2012). In southeastern Australia, Cattle (2016) makes a strong case for an episodic version of a Dust Bowl that continued for 50 years (1895-1945), a period of depressed rainfall when marginal lands were actively cropped and grazed, and rabbits were a burgeoning grazing pest.

\subsection{Transport phase}

Dust suspended in the atmosphere has implications for human health due to its physical, chemical and biological properties and this is one of the best studied aspects of desert dust hazards 
(Griffin, 2007; Sandstrom and Forsberg, 2008; Goudie, 2014; Sprigg, 2016). Exposure to dust in the atmosphere can result in conjunctivitis and dermatological disorders while inhalation can cause respiratory illnesses such as silicosis (also known as desert lung syndrome) and act as a trigger for many others, including asthma, bronchitis, emphysema and chronic obstructive pulmonary disease. Some storms are associated with very high atmospheric dust concentrations that frequently exceed recommended health levels for particulate matter. In extreme cases, people and animals caught in a severe storm may lose their lives due to suffocation. A major dust storm in April 1895 in the US state of Colorado was reported to have caused the loss of $20 \%$ of the cattle in the east of the state (Idso, 1976).

Particle size is the main determinant of where dust comes to rest in the respiratory tract once inhaled. A distinction is commonly highlighted between particles $<10 \mu \mathrm{m}\left(\mathrm{PM}_{10}\right)$ in diameter, which can penetrate into the lungs, and those with diameter $<2.5 \mu \mathrm{m}\left(\mathrm{PM}_{2.5}\right)$ which penetrate into deep lung tissue. Various health authorities have issued air quality guidelines with two components (Table 3): acceptable atmospheric concentrations at the chronic level (annual mean) and acute level (24-hour mean), although the World Health Organization (WHO) points out that "The risk for various outcomes has been shown to increase with exposure and there is little evidence to suggest a threshold below which no adverse health effects would be anticipated." (WHO, 2006, p9).

Table 3. Air quality guidelines for particulate matter

\begin{tabular}{|l|r|r|r|r|}
\hline Body & $\begin{array}{l}\text { PM..5 annual } \\
\text { mean } \\
\left(\mu \mathrm{g} / \mathbf{m}^{\mathbf{3}}\right)\end{array}$ & $\begin{array}{l}\text { PM2.5 24- } \\
\text { hour mean } \\
\left(\boldsymbol{\mu g} / \mathbf{m}^{\mathbf{3}}\right)\end{array}$ & $\begin{array}{l}\text { PM10 annual } \\
\text { mean }\left(\boldsymbol{\mu g} / \mathbf{m}^{3}\right)\end{array}$ & $\begin{array}{l}\text { PM10 24- } \\
\text { hour mean } \\
\left(\boldsymbol{\mu g} / \mathbf{m}^{\mathbf{3}}\right)\end{array}$ \\
\hline World Health Organization & 10 & 25 & 20 & 50 \\
\hline European Commission & 25 & N/A & 40 & 50 \\
\hline $\begin{array}{l}\text { Australian National } \\
\text { Environment Protection } \\
\text { Council }\end{array}$ & 8 & 25 & N/A & 50 \\
\hline $\begin{array}{l}\text { Chinese Ministry of } \\
\text { Environmental Protection } \\
\text { (Class II level) }\end{array}$ & 35 & 75 & 70 & 150 \\
\hline $\begin{array}{l}\text { Pollution Control Board of } \\
\text { India }\end{array}$ & 40 & 60 & 60 & 100 \\
\hline $\begin{array}{l}\text { US Environmental } \\
\text { Protection Agency }\end{array}$ & 12 & 35 & N/A & 150 \\
\hline
\end{tabular}

Even so, such guideline values are regularly exceeded in, and downwind of, dust source areas. Desert dust is by no means the only source of atmospheric particulates, of course. Other common sources include volcanoes and sea salt aerosols, as well as the internal combustion engine and a variety of industries - and these sources are frequently combined - but Goudie (2014, Table 5a) shows a large number of desert cities where annual mean $\mathrm{PM}_{10}$ values are an order of magnitude higher than the WHO guideline. Atmospheric concentrations in individual dust events are characteristically much higher still. $\mathrm{PM}_{10}$ levels of $1,000 \mu \mathrm{g} / \mathrm{m}^{3}$ and more have been recorded in dust storms in many desert areas and extreme values exceed 10,000 $\mu \mathrm{g} / \mathrm{m}^{3}$ (e.g. Leys et al., 2011; Kaly et al., 2015).

Annual average $\mathrm{PM}_{2.5}$ particulate concentrations for 15 locations in the Middle East presented by Engelbrecht et al. (2009) range from 35 to $111 \mu \mathrm{g} / \mathrm{m}^{3}$ and are, therefore, all higher than the air quality guidelines shown in Table 3. Very high $\mathrm{PM}_{2.5}$ levels have been recorded in intense dust storms. Raman et al. (2014) measured a peak hourly $\mathrm{PM}_{2.5}$ concentration of $907 \mu \mathrm{g} / \mathrm{m}^{3}$ in a dry thunderstorm ('haboob') dust wall in the southwestern USA, but an hourly maximum PM $_{2.5}$ concentration reached $2899 \mu \mathrm{g} / \mathrm{m} 3$ at Dalanzadgad during a dust storm in the Mongolian Gobi Desert (Jugder et al., 2011). The maximum daily 
average concentration measured during a dust storm in western Saudi Arabia was $594 \mu \mathrm{g} / \mathrm{m} 3$

(Alghamdi et al., 2015).

The very large quantities of desert dust moved during some long-distance transport events means that high atmospheric concentrations can be experienced at considerable distances from dust source areas. Table 4 shows some of the $\mathrm{PM}_{10}$ levels recorded after dust has been carried between $500 \mathrm{~km}$ and $16,000 \mathrm{~km}$ from major sources, events that frequently take several days. Long-range transport of desert dust from China and Mongolia across the Korean peninsula is so common that the Korea Meteorological Administration has established a public information system to warn its citizens of possible health effects (Korea Meteorological Administration, 2016). There are two levels of notice:

- Advisory, issued when the hourly mean $\mathrm{PM}_{10}$ concentration is expected to exceed $400 \mu \mathrm{g} \mathrm{m}^{-3}$ for over 2 hours.

- Warning, issued when the hourly mean $\mathrm{PM}_{10}$ concentration is expected to exceed $800 \mu \mathrm{g} \mathrm{m}^{-3}$ for over 2 hours.

264 Table 4. Maximum observed PM10 levels in long-distance dust transport events

\begin{tabular}{|c|c|c|c|c|c|}
\hline Location & $\begin{array}{l}\text { Concentration } \\
\left(\mu \mathrm{g} \mathrm{m}^{-3}\right)\end{array}$ & Date & Dust source & $\begin{array}{l}\text { Distance } \\
\text { transported } \\
(\mathbf{k m})\end{array}$ & Reference \\
\hline \multicolumn{6}{|l|}{ Saharan dust } \\
\hline Mbour, Senegal & $\begin{array}{r}1600 \text { (daily } \\
\text { mean) }\end{array}$ & 9 March 2006 & $\begin{array}{l}\text { Mauritania-Mali- } \\
\text { Algeria }\end{array}$ & $>1,000$ & $\begin{array}{r}\text { Skonieczny et } \\
\text { al. (2011) }\end{array}$ \\
\hline Praia, Cape Verde & $\begin{array}{r}500(5-\min \\
\text { mean })\end{array}$ & $\begin{array}{r}18 \text { January } \\
2011\end{array}$ & Western Sahara & $>1,000$ & Pio et al. (2014) \\
\hline $\begin{array}{l}\text { Cayenne, French } \\
\text { Guiana }\end{array}$ & $\begin{array}{r}100 \text { (daily } \\
\text { mean) }\end{array}$ & 30 April 2009 & Sahel and Sahara & $>5,000$ & $\begin{array}{r}\text { Prospero et al. } \\
\text { (2014) }\end{array}$ \\
\hline Athens, Greece & $\begin{array}{r}200 \text { (daily } \\
\text { mean) }\end{array}$ & 17 April 2005 & Libya & $>500$ & $\begin{array}{r}\text { Kaskaoutis et al. } \\
\text { (2008) }\end{array}$ \\
\hline $\begin{array}{l}\text { La Seyne sur Mer, } \\
\text { France }\end{array}$ & 214 (peak) & $\begin{array}{r}21 \text { February } \\
2004\end{array}$ & $\begin{array}{l}\text { Southern Morocco and } \\
\text { Algeria }\end{array}$ & $>2,000$ & $\begin{array}{r}\text { Masson et al. } \\
\text { (2010) }\end{array}$ \\
\hline Brussels, Belgium & 150 (peak) & $\begin{array}{r}29 \text { March } \\
2007 \\
\end{array}$ & Northern Sahara & $>4,000$ & $\begin{array}{r}\text { Vanderstraeten } \\
\text { et al. (2008) } \\
\end{array}$ \\
\hline \multicolumn{6}{|c|}{ Northeast Asian dust } \\
\hline Chongwon, Korea & $\begin{array}{r}1,779 \text { (daily } \\
\text { mean) }\end{array}$ & $\begin{array}{r}21 \text { March } \\
2002\end{array}$ & $\begin{array}{l}\text { Gobi Desert in } \\
\text { Mongolia and Inner } \\
\text { Mongolia }\end{array}$ & $>1,900$ & $\begin{array}{r}\text { Chung et al. } \\
\text { (2003) }\end{array}$ \\
\hline Seoul, Korea & $\begin{array}{r}880(\max \\
\text { hourly mean) }\end{array}$ & 30 May 2008 & $\begin{array}{l}\text { Inner Mongolia, Man- } \\
\text { Ju, and Ordos areas, } \\
\text { China }\end{array}$ & $>1,000$ & $\begin{array}{r}\text { Kim et al. } \\
(2010)\end{array}$ \\
\hline Banryu, Japan & 800 (peak) & 2 April 2007 & Gobi Desert, Mongolia & $>2,500$ & $\begin{array}{r}\text { Yumimoto et al. } \\
\text { (2008) }\end{array}$ \\
\hline Yasuhara, Japan & 230 & $\begin{array}{r}16 \text { March } \\
2009\end{array}$ & $\begin{array}{l}\text { Gobi Desert, } \\
\text { Mongolia/China border }\end{array}$ & $>2,000$ & $\begin{array}{r}\text { Sugimoto et al. } \\
\text { (2013) }\end{array}$ \\
\hline Northern Taiwan & 400 & 28 April 2000 & $\begin{array}{l}\text { Mongolia and Inner } \\
\text { Mongolia }\end{array}$ & 3,000 & Lin (2001) \\
\hline West coast, USA & $>100$ & 29 April 1998 & Gobi desert & $>16,000$ & $\begin{array}{r}\text { Husar et al. } \\
(2001)\end{array}$ \\
\hline \multicolumn{6}{|l|}{ Middle Eastern dust } \\
\hline Limassol, Cyprus & 7,600 (peak) & $\begin{array}{r}8 \text { September } \\
2015 \\
\end{array}$ & Northern Syria and Iraq & $>500$ & $\begin{array}{r}\text { Mamouri et al. } \\
\text { (2016) }\end{array}$ \\
\hline Sanandaj, Iran & 5,616 (peak) & 5 July 2009 & $\begin{array}{l}\text { Northern Saudi Arabia, } \\
\text { Western Iraq and } \\
\text { Eastern Syria }\end{array}$ & 1,000 & $\begin{array}{r}\text { Amanollahi et } \\
\text { al. (2011) }\end{array}$ \\
\hline
\end{tabular}




\begin{tabular}{|l|r|r|l|r|r|}
\hline Delhi, India & $\begin{array}{r}990(8 \text {-hour } \\
\text { mean })\end{array}$ & $\begin{array}{r}21 \text { March } \\
2012\end{array}$ & Arabian Peninsula & $>1,500$ & $\begin{array}{r}\text { Yarragunta \& } \\
\text { Srivastava } \\
(2016)\end{array}$ \\
\hline Australian dust & $\begin{array}{r}2,426 \text { (daily } \\
\text { mean) }\end{array}$ & $\begin{array}{r}23 \text { September } \\
2009\end{array}$ & Lake Eyre Basin & $>700$ & $\begin{array}{r}\text { Leys et al. } \\
(2011)\end{array}$ \\
\hline $\begin{array}{l}\text { Newcastle, } \\
\text { Australia }\end{array}$
\end{tabular}

Many epidemiological studies show possible associations of dust exposure with increases in mortality and hospital visits and admissions due to respiratory and cardiovascular diseases. The effects of desert dust outbreaks on asthma incidence has attracted considerable research effort in numerous parts of the world, both in desert areas such as Australia (Rutherford et al., 1999) and the Middle East (Thalib and Al-Taiar, 2012), but also in areas affected by frequent long-range transport, including northeast Asia (Lee and Lee, 2013) and southern Europe (Karanasiou et al., 2012). However, desert dust is just one of a host of factors - including genetics, environmental exposure to allergens, and non-specific adjuvant factors such as air pollution, tobacco smoke and infections - that may influence the development and expression of a respiratory allergic disease such as asthma. In a review of how air pollution may be associated with allergies and asthma, Kim et al. (2013) found that exposure to atmospheric particulate matter - including desert dust, soot, smoke and other aerosols - can exacerbate symptoms in asthmatics, as can a number of other pollutants, including nitrogen dioxide, ozone, sulfur dioxide, volatile organic compounds (VOCs), dust mites, pet allergens and mould. Evaluating the impact of individual components is, they conclude, "no easy task".

Respiratory disease may be a chronic condition amongst farmers who are exposed to soil dust on a regular basis during field activities such as ploughing and harvesting (Smith and Lee, 2003). Agricultural workers are typically exposed to a range of hazardous respiratory agents, and it is difficult to identify specific individual causes of specific ailments, but acute and chronic bronchitis, chronic obstructive airways disease, and interstitial lung disease are thought to be predominantly linked to mineral dust exposure, particularly in dryland farming areas (Schenker, 2000).

A range of cardiovascular disorders - including stroke, heart failure, myocardial infarction, arrhythmias and venous thromboembolism - has been linked to short- and long-term exposure to high atmospheric particulate levels, and $\mathrm{PM}_{2.5}$ in particular (Martinelli et al., 2013) although, as in the case of asthma, attributing the individual effects of a variety of factors remains a significant challenge and questions of causality are yet to be completely answered. Nevertheless, Lary et al. (2014) suggest that the widest variety of health impacts are associated with $\mathrm{PM}_{2.5}$ when compared to $\mathrm{PM}_{10}$ or ultra-fine particles $(<100 \mathrm{~nm})$, although they also highlight the uneven spread of studies on the various health outcomes as related to particulate matter (see their Table 1). One global study that modelled the effects of airborne desert dust on air quality and premature mortality concluded that the global fraction of cardiopulmonary deaths caused by $\mathrm{PM}_{2.5}$ desert dust particles was about $1.8 \%$. This proportion was much higher, at about 15-50 \%, for the 20 countries most affected by desert dust: those located in the broad swath of desert terrain stretching from North Africa across the Middle East and into Asia (Giannadaki et al., 2014).

While there is widespread agreement that airborne particulate matter is responsible for globally important influences on premature human mortality, our understanding of the relative importance of the different chemical components of this material for these effects is less well understood (Fuzzi et al., 2015). The main component of desert dust is silica and mineralogical studies indicate that the great bulk of this silica is made up of quartz. Reviewing a range of samples from various world deserts, $\mathrm{Al}_{2} \mathrm{O}_{2}$, $\mathrm{Fe}_{2} \mathrm{O}_{3}, \mathrm{CaO}, \mathrm{MgO}$ and $\mathrm{K}_{2} \mathrm{O}$ were found to be typically present (Goudie and Middleton, 2006). Depending on the nature of source sediments, a range of other toxic or irritating materials may occur, including heavy metals and pesticide residues (e.g. Ataniyazova et al., 2001), polychlorinated biphenyls or PCBs (e.g. Garrison et al., 2006), radionuclides (e.g. Csavina et al., 2012) and arsenic (e.g. Soukup et al. 2012). Where plumes are blown across heavily industrialized and polluted regions, desert dust is commonly mixed with other atmospheric pollutants (Chin et al., 2007). 
Microbiological studies have established that desert dust can contain a wide variety of microorganisms - including fungi, bacteria and viruses - capable of causing disease in a range of organisms, such as trees, crop plants and animals as well as people (Kellogg and Griffin, 2006). A thorough review of pathogenic microorganisms dispersed in desert dust and their implications for agriculture is given by Gonzalez-Martin et al. (2014). In human populations, a number of diseases are linked to desert aerosols. Exposure to desert dust may explain part of the variability in the incidence of Kawasaki disease, which causes an inflammation of the blood vessels that can lead to heart disease. Cases of Kawasaki disease diagnosed in Japan and Hawaii have been linked to dust transported from Asian deserts and cases in Chile have been associated with dust transport from the Atacama Desert (Jorquera et al., 2015). Rodo et al. (2014) suggest that a fungus of the Candida species could be the wind-borne infectious agent that spreads the disease. Coccidioidomycosis, a sometimes deadly fungal disease occurring only in the Americas, is caused by two species of fungus entrained from dryland soils in the US southwest, northern Mexico and northeastern Brazil. An estimated 100,000 primary coccidioidal infections occur in humans each year in the endemic areas of the USA but Mexico has the largest number of reported cases (Hector and Laniado-Laborin, 2005).

There have been relatively few studies about desert dust impacts on air quality and human health in West Africa (de Longueville et al., 2013), despite the proximity of the Sahara, and the dearth of data is a major constraint on our understanding of the health impacts in this region. One serious health problem that has been related to West Africa's high atmospheric dust loads is meningococcal meningitis. The incidence of epidemics in the Sahelian zone, otherwise known as the Meningitis Belt, appears to be related to Saharan dust intrusions brought by the Harmattan (Thomson et al., 2009), and there are several possible explanations of how dust may be linked causally to the epidemics (Table 5). The seriousness of the issue is highlighted by Jusot et al. (2016) who emphasise that the Sahel has the world's highest attack rate $(10$ per 100,000$)$ and case fatality rates $(15 \%)$ for bacterial meningitis: 350 million people being at risk across 21 countries. Many of these people are subsistence farmers and herders, for whom the debilitating effects of disease are particularly critical. In a survey of farmers' views about the relative importance of constraints to agricultural production in Niger, $80 \%$ of villagers $(n=892)$ reported severe health symptoms during the Harmattan season. Interestingly, these health problems related to dust storms were of more concern than crop damage or loss of topsoil to wind erosion (Bielders et al., 2001).

Table 5. Possible explanations for the impact of desert dust on meningitis epidemics in West Africa

\begin{tabular}{|l|r|}
\hline Hypothesis & Reference \\
\hline $\begin{array}{l}\text { Increase in invasion rate (i.e. shift from carrier to infected status) due to high } \\
\text { dust loads and persistent low humidity damaging immune defences in the mouth } \\
\text { and easing bacterial invasion }\end{array}$ & Moore (1992) \\
\hline $\begin{array}{l}\text { Higher transmission levels due to changes in living habits, such as proximity of } \\
\text { individuals taking refuge from dusty winds }\end{array}$ & Remy (1990) \\
\hline $\begin{array}{l}\text { Co-occurrence of viral respiratory infections weakening the immune system and } \\
\text { easing transmission and invasion by bacteria }\end{array}$ & $\begin{array}{r}\text { Mueller et al. } \\
\text { (2008) }\end{array}$ \\
\hline $\begin{array}{l}\text { Neisseria bacteria, responsible for meningitis, require iron-rich dust to grow and } \\
\text { become virulent }\end{array}$ & $\begin{array}{r}\text { Noinaj et al., } \\
(2012)\end{array}$ \\
\hline
\end{tabular}

Desert dust in suspension presents problems for several forms of communication, including radio waves and microwaves which pass through the atmosphere. The operations of terrestrial and satellite communications are hampered by attenuation induced by absorption and scattering by dust and sand particles in the atmosphere (Saleh and Abuhdima, 2011). Generally, the issue is greater for shorter wavelengths. Electric fields, some larger than $200 \mathrm{kV} / \mathrm{m}$, have been measured in dust storms and 
might play an important role in saltation and dust emission processes (Kok and Renno, 2006). Such electric forces also present hazards in themselves.

Dust storms can result in dangers for modes of transport and an increase in accidents in the air and on the ground. Poor visibility is a frequent cause, sometimes in combination with the adverse mechanical effects of dust. Holyoak et al. (2011) reported that a particularly severe dust event in Australia in 2009 resulted in the grounding of a large portion of the air medical retrieval fleet in the state of Queensland. Several reasons were cited, including breaching of the minimum visibility level for instrument landing systems, severe atmospheric turbulence, and the risk of damage to moving parts, windscreens, engine intakes and air filtration systems. For these reasons airports, and on occasion seaports and roads, are frequently closed during intense dust events.

Aircraft that do fly in dusty conditions require higher maintenance and replacement costs for mechanical equipment. Helicopter engines are especially susceptible to large amounts of dust and sand ingestion during hover, take-off, and landing. The loss in power and surge margins as a result of compressor blade erosion during the first Gulf War resulted in some military helicopter units being withdrawn after fewer than 20 hours of field operations (Hamed et al., 2006).

Although often mentioned in the literature as a transport hazard, this is a relatively under-studied aspect of desert dust. Indeed, the hazards to aviation presented by volcanic ash clouds have attracted much greater attention, despite being much less frequent and less widespread (Weinzierl et al., 2012). In a rare national study using air traffic incident reports in Australia over the period 1969-2010, Baddock et al. (2013) concluded that atmospheric dust in Australia represents at worst an inconvenience and economic cost since nearly two thirds of the dust-caused air safety issues identified related to navigational problems. There were no reported deaths over the 42 -year period studied and these authors noted that improvements in aviation technology were at least partly responsible for a reduction in incidents in more recent decades. However, in other parts of the world, where equipment is often older and safety standards may be lower, dust storms have been implicated in a number of aircraft accidents involving fatalities as shown in Table 6 which has been compiled using media reports. Attribution of cause in such crashes is seldom straightforward, and often involves a combination of factors, but all the accidents shown in Table 6 involved dust storms to some extent. Similarly, an intense dust storm played a critical part in a collision between a helicopter and fixed-wing aircraft in the Lut Desert, Iran during an attempt by the US military to rescue hostages held in the US embassy in Tehran in 1980 (Thomas, 1987). Eight men died in the crash, which also had considerable political repercussions.

\section{Table 6. Some fatal commercial aircraft crashes attributed to dust storms}

\begin{tabular}{|l|l|l|r|}
\hline Location & Date & Airline & Fatalities \\
\hline Côte d'Ivoire & 30th January 2000 & Kenya Airways & 179 dead \\
\hline Tunis, Tunisia & 7th May 2002 & EgyptAir & 18 dead \\
\hline Faridabad, India & 25th May 2011 & Air Chartered Services & 10 dead \\
\hline Talodi, Sudan & 19th August 2012 & Sudan Airways & 31 dead \\
\hline
\end{tabular}

383

384

385

386

387

388

389

390

391

392
The change in atmospheric conditions to near-zero visibility may be very sudden when caused by the arrival of a dust wall associated with a haboob. These dust walls were responsible for 32 multiple accidents between 1968 and 1975 on Interstate 10 in Arizona, USA (Brazel and Hsu, 1981), a stretch of highway that remains susceptible to multiple pile-ups caused by dust storms (Reid et al., 2016). When conditions are appropriate, this sort of road traffic disaster can occur even outside the drylands, as in northern Germany in April 2011 when dust blown from nearby potato fields led to a massive pile-up on the adjacent autobahn A19 in which 8 people died (Deetz et al., 2016). However, there are very few studies of such road traffic accidents outside the USA, where some 62 deaths nationally were related to dust storms affecting road vehicles between 1980 and 2005 (Ashley and Black, 2008). 
Strong, erosive winds also have impacts on rail communications. Cheng et al. (2015) report that direct destructive effects on railways in northwestern China result from copious airborne particles that can break windows, damage carriages and even blow over the train, as well as reduced visibility that results in trains being stopped for safety reasons.

\subsection{Deposition phase}

Desert dust deposition rates can be considerable, with annual amounts frequently exceeding 100 $\mathrm{t} / \mathrm{km}^{2}$ close to major sources (e.g. McTainsh and Walker, 1982; Singer et al., 2003; Al-Awadhi and AlShuaibi, 2013) and declining with distance transported. The deposition of dust has implications for residents both within and beyond desert areas. Although some of the issues are difficult to separate from those associated with dust in transport, dust deposition can lead to the contamination of drinking-water with microorganisms mentioned above and/or with anthropogenic materials picked up and transported in dust events. These include pesticides, herbicides, heavy metals, dioxins, and radioactive isotopes.

The chemical effect of desert dust on water quality has been established in the Negev Desert by Nativ et al. (1997). The high salinity typical of most groundwater in arid zones is often attributed primarily to high evaporation rates and limited recharge, but the high levels of $\mathrm{NaCl}$ in precipitation, surface water, vadose water and groundwater in the Negev are intimately linked to abundant dust that provides a steady flux of minerals to the atmosphere which are dissolved by the scant precipitation. Similar contamination can occur when dusts laden with salts are deposited on soils. Soil salinization is a particular issue in the zone surrounding the desiccated former lakebed of the Aral Sea (Figure 3), endangering the productivity of nearby rangeland and agricultural areas. Prevailing winds from the north and north-east mean the most serious impacts occur on the Usturt Plateau to the west of the Aral Sea and the Amudarya delta to the south (Issanova et al., 2015).

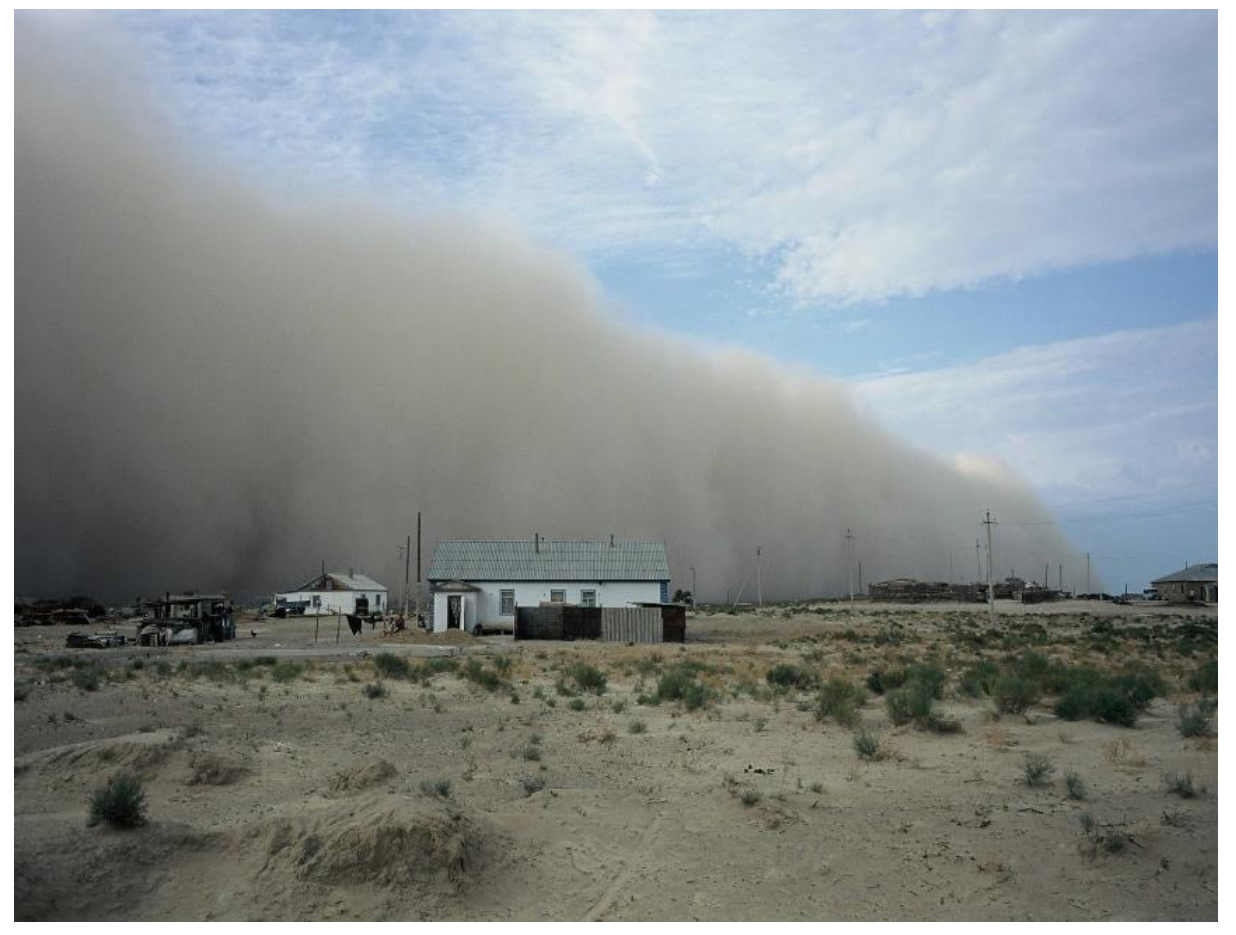

Figure 3. Dust storm approaching the village of Qulandy, near the Aral Sea in Kazakhstan (Photo: NM) 


\section{Economic assessments of the desert dust hazard}

Individual events of course result in multiple impacts. The effects of a severe dust storm in eastern Mongolia on 26-27 May 2008 are documented by Jugder et al. (2011): 52 people were killed, among them 14 children, and about 242,000 head of livestock. There was also damage to 110 buildings, 221 homes and 668 telegraph poles. The total economic cost of this single event in rural Mongolia was estimated to be some 640.2 million Tugrig (US\$457,000). Such large-scale dust events frequently cause disruption internationally. A regional dust haze that affected many countries in the Middle East in early April 2015 resulted in flights being diverted, cancelled or delayed at international airports in Bahrain, Dubai and Muscat. Local media reported that all schools were closed in Qatar and eastern Saudi Arabia and that high atmospheric dust loads had caused a spike in patient numbers at hospitals in the United Arab Emirates. Bus services between Dubai and Abu Dhabi were cancelled as visibility was reduced to zero, and the extreme weather conditions were blamed for causing 82 accidents on the roads in Sharjah.

Given the importance of desert dust as a hazard to human societies, as detailed in this paper, it is surprising to note that there have been relatively few attempts to assess their impacts in economic terms. One early estimate of the economic cost of a specific dust-related disease, an epidemic of Valley Fever (coccidioidomycosis) in the US southwest over the period 1991-94, was reported by Kirkland and Fierer (1996). The outbreak was considered to have cost more than US\$66 million in direct medical expenses and time lost from work in Kern County, California. A more recent estimate, for the entire US state of Arizona for the year 2007, put the charges for 1735 hospital visits for Valley Fever at US\$86 million (Sprigg et al., 2014). Costs to a branch of the transport sector, the aviation industry, were estimated for 
the year 2002 in South Korea by Kang et al. (2004). They calculated that the total cost of 102 flights being cancelled that year due to desert dust in the atmosphere was US\$578,000.

Total cost estimates for some individual dust events are shown in Table 7, reflecting a wide range of economic impacts. Both on-site and off-site costs associated with a single large storm that affected the Australian state of New South Wales in 2009 were estimated at Aus\$299 million (US\$219m), with most of that accounted for by household cleaning and disruption to commercial activities (retail and service industries), air transport and construction (Tozer and Leys, 2013). The large difference in estimated costs between the two events shown in Table 7 is in part due to different assessment methods, as well as the contrast between a rural event in a developing country (Mongolia) and an event that impacted several major cities in a more prosperous economy (Australia).

\section{Table 7. Economic cost estimates of individual dust events}

\begin{tabular}{|l|l|l|l|}
\hline Item & Location & Cost (US\$) & Reference \\
\hline $\begin{array}{l}\text { Total local cost, dust storm } \\
\text { 26-27 May 2008 }\end{array}$ & Eastern Mongolia & $0.46 \mathrm{~m}$ & Jugder et al. (2011) \\
\hline $\begin{array}{l}\text { On- and off-site costs Red } \\
\text { Dawn dust storm 23 } \\
\text { September 2009 }\end{array}$ & $\begin{array}{l}\text { New South Wales, } \\
\text { Australia }\end{array}$ & $219 \mathrm{~m}$ & Tozer \& Leys (2013) \\
\hline
\end{tabular}

Similar assessments of the economic burden on an annual basis have been made in a slightly larger number of cases, as shown in Table 8. The work of three separate South Korean studies, using different methodologies to establish the socio-economic cost to the country of yellow dust transported from Northeast Asian deserts in the year 2002, is compared by Jeong (2008). Estimates range from a low of US\$3,900 million to a maximum of US\$7,300 million. Jeong points out that the average of the two, US\$5,600 million, is equivalent to US\$ 117.00 per South Korean inhabitant or $0.8 \%$ of GDP. Meibodi et al. (2015) took three main sectors (health, transport and agriculture) into account when calculating their 2013 costs of dust storms in Iran and Iraq, each in the region of US $\$ 1,000$ million. An earlier estimate by Pimentel et al. (1995) for wind erosion in the USA assessed just the off-site costs to reach a total of US $\$ 9,600$ million.

\section{Table 8. Annual economic cost estimates of desert dust events}

\begin{tabular}{|l|l|r|r|}
\hline Item & Location & Cost (US\$) & \multicolumn{1}{l|}{ Reference } \\
\hline Total costs & South Korea & 5.6bn & Jeong (2008) \\
\hline Total costs & Iran & $1.0 \mathrm{bn}$ & Meibodi et al. (2015) \\
\hline Total costs & Iraq & $1.4 \mathrm{bn}$ & Meibodi et al. (2015) \\
\hline Off-site costs & USA & $9.6 \mathrm{bn}$ & Pimentel et al. (1995) \\
\hline Total costs & Beijing, China & $265 \mathrm{~m}$ & Ai and Polenske (2008) \\
\hline Total costs & Yazd plain, Iran & $6.8 \mathrm{~m}$ & Ekhtesasi \& Sepehr (2009) \\
\hline Off-site costs & Seistan Region, Iran & $25 \mathrm{~m}$ & Miri et al. (2009) \\
\hline Off-site costs & South Australia & $17 \mathrm{~m}$ & Williams \& Young (1999) \\
\hline
\end{tabular}

An assessment of the total off-site costs of the dust storm hazard in the state of South Australia put it at Aus\$23 million (US\$17m) a year on average (Williams and Young, 1999). Miri et al. (2009) 
made a similar assessment of the Seistan region in Iran using questionnaires and estimated a total economic cost due to physical damage and loss of productive man-hours of US\$125 million over a fivefive-year period. An attempt to assess the total cost of atmospheric soil dust to the city of Beijing in China in the year 2000 identified a considerable decrease in output from urban agriculture, manufacturing, construction, transportation, trade and catering services (Ai and Polenske, 2008). In total, the cost of these direct impacts came to US\$265 million.

A number of agricultural studies have estimated the on-site costs of soil erosion by wind on farmers' fields. One such assessment in the 1980s established that the on-site crop and soil damage in the US state of New Mexico totalled US\$10 million per year (Davis \& Condra, 1989), although this was dwarfed by the annual off-site wind erosion costs in New Mexico of US\$466 million (Huszar \& Piper, 1986). An EU research project, Wind Erosion on European Light Soils (WEELS), analysed the effects of cultivating a range of crop types (Riksen and De Graaff, 2001). The damage assessed consisted mainly of crop losses and additional inputs in the case of re-sowing. Depending on the crop the average annual on-site costs in high-risk areas amounted to about $€ 60$ (US\$55) per hectare, but for sugar beet and oilseed rape the costs could be as much as $€ 500$ (US\$450) per hectare once in five years.

\section{Conclusions}

Drylands present a range of hazards to their human occupants, of which dust storms are one of the most serious, but the significance of desert dust hazards also affects many people far beyond the dryland realm due to long-distance dust transport. Living in drylands and on their margins frequently involves society coping with high levels of risk, often stemming from natural hazards such as dust storms. Coping with these risks, through prediction, adaptation and mitigation measures, depends on a thorough understanding of the hazards and their impacts. The important implications that dust storms have for the environment and their many impacts within the Earth system have been an impetus for a considerable increase in desert dust research in recent years, but research into the hazard implications of dust has lagged somewhat. As the wide range of direct and costly impacts indicates, desert dust storms warrant greater attention in this respect.

There are several areas that deserve more research effort. Our knowledge and understanding of desert dust source regions, processes of emission and transport, remain incomplete, which feeds into our attempts to model desert dust movement and its impacts. Studies of some forms of dust storm hazard, such as wind erosion in agricultural areas, are relatively mature, but others remain under-studied. The latter group includes the impacts on transport, making causal associations between exposure to desert dust particles and adverse human health effects, and the effects of dust deposition on plants. Better understanding of such subjects will also improve another facet of desert dust research that remains in its infancy: the economic impact assessment of dust events.

All aspects of desert dust hazards have received more research attention in some parts of the world than others. West Africa, which lies in the pathway of the world's largest desert dust flows, is notably under-studied in most regards. Improved knowledge of desert dust hazards, in all affected areas, is needed for a satisfactory response to the United Nations call for countries to address the challenges of dust storms cost-effectively through appropriate policy measures. 


\section{References}

Ai, N., Polenske, K.R., 2008. Socioeconomic impact analysis of yellow-dust storms: An approach and case study for Beijing. Econ. Systems Res. 20(2), 187-203.

Al-Awadhi, J.M., Al-Shuaibi, A.A., 2013. Dust fallout in Kuwait city: deposition and characterization. Sci. Total Environ. 461, 139-148.

Al-Dousari, A.M., Al-Awadhi, J., 2012. Dust fallout in northern Kuwait, major sources and characteristics. Kuwait J. Sci. Eng. 39(2A),171-187.

Alghamdi, M.A., Almazroui, M., Shamy, M., Redal, M.A., Alkhalaf, A.K., Hussein, M.A., Khoder, M.I., 2015. Characterization and elemental composition of atmospheric aerosol loads during springtime dust storm in western Saudi Arabia. Aerosol Air Qual. Res. 15, 440-453.

Amanollahi, J., Kaboodvandpour, S., Abdullah, A. M., Ramli, M. F. 2011. Accuracy assessment of moderate resolution image spectroradiometer products for dust storms in semiarid environment. International Journal of Environmental Science \& Technology, 8(2), 373-380.

Ashley, W.S., Black, A.W., 2008. Fatalities associated with nonconvective high-wind events in the United States. J. Appl. Meteorol. 47, 717e725.

Ataniyazova, O.A., Baumann, R.A., Liem, A.K.D., Mukhopadhyay, U.A., Vogelaar, E.F., Boersma, E.R., 2001. Levels of certain metals, organochlorine pesticides and dioxins in cord blood, maternal blood, human milk and some commonly used nutrients in the surroundings of the Aral Sea (Karakalpakstan, Republic of Uzbekistan). Acta Paediatrica, 90(7), 801-808.

Baddock, M.C., Strong, C.L., Murray, P.S., McTainsh, G.H., 2013. Aeolian dust as a transport hazard. Atmos. Environ. 71, 7-14.

Bielders, C.L., Alvey, S., Cronyn, N., 2001. Wind erosion: the perspective of grass-roots communities in the Sahel. Land Degrad. Dev. 12, 57-70.

Bory, A.J.M., Biscaye, P.E., Grousset, F.E., 2003. Two distinct seasonal Asian source regions for mineral dust deposited in Greenland (NorthGRIP). Geophys. Res. Lett. 30(4).

Boy, J., Wilcke, W., 2008. Tropical Andean forest derives calcium and magnesium from Saharan dust. Glob. Biogeochem. Cycles 22(1).

Brazel, A., Hsu, S., 1981. The climatology of hazardous Arizona dust storms. Geol. Soc. of America Special Papers 186, 293-303.

Bristow, C.S., Drake, N., Armitage, S., 2009. Deflation in the dustiest place on Earth: the Bodélé Depression, Chad. Geomorphology 105(1), 50-58.

Bullard, J., Baddock, M., McTainsh, G., Leys, J., 2008. Sub- basin scale dust source geomorphology detected using MODIS. Geophys. Res. Lett. 35(15).

Bullard, J.E., Harrison, S.P., Baddock, M.C., Drake, N., Gill, T.E., McTainsh, G., Sun, Y., 2011. Preferential dust sources: A geomorphological classification designed for use in global dust- cycle models. J. Geophys. Res.: Earth Surface, 116(F4).

Bullard, J.E., Baddock, M., Bradwell, T., Crusius, J., Darlington, E., Gaiero, D., Gassó, S., Gisladottir, G., Hodgkins, R., McCulloch, R., McKenna- Neuman, C., 2016. High- latitude dust in the Earth system. Rev. Geophys. doi 10.1002/2016RG000518.

Burkhardt, J., 2010. Hygroscopic particles on leaves: nutrients or desiccants? Ecol. Monogr. 80, 369399.

Cakmur, R.V., Miller, R.L., Perlwitz, J., Geogdzhayev, I.V., Ginoux, P., Koch, D., Kohfeld, K.E., Tegen, I., Zender, C.S., 2006. Constraining the magnitude of the global dust cycle by minimizing the difference between a model and observations. J. Geophys. Res.-Atmos 111(D6).

Cattle, S.R., 2016. The case for a southeastern Australian Dust Bowl, 1895-1945. Aeolian Res. 21, 1-20.

Changery, M.J., 1983. Dust climatology of the western United States (No. NUREG/CR-3211). National Climatic Center, Asheville, NC (USA).

Cheng, J.J., Jiang, F.Q., Xue, C.X., Xin, G.W., Li, K.C., Yang, Y.H., 2015. Characteristics of the disastrous wind-sand environment along railways in the Gobi area of Xinjiang, China. Atmos. Environ. 102, 344-354. 
Chepil, W.S., Woodruff, N.P., 1963. The physics of wind erosion and its control. Adv. Agron. 15, 211302.

Chin, M., Diehl, T., Ginoux, P., Malm, W., 2007. Intercontinental transport of pollution and dust aerosols: implications for regional air quality. Atmos. Chem. Phys. 7(21), 5501-5517.

Choun, H.F., 1936. Duststorms in the southwestern plains area. Mon. Weather Rev. 64, 195.

Chung, Y.S., Kim, H.S., Dulam, J., Harris, J., 2003. On heavy dustfall observed with explosive sandstorms in Chongwon-Chongju, Korea in 2002. Atmos. Environ. 37(24), 3425-3433.

Cook B.I., Miller R.L., Seager R., 2009. Amplification of the N American Dust Bowl drought through human-induced land degradation. Proc Nat Acad Sci 106:4997-5001.

Cook, B.I., Seager, R., Smerdon, J.E., 2014. The worst North American drought year of the last millennium: 1934. Geophys. Res. Lett. 41, 7298-7305,doi:10.1002/2014GL061661.

Coudé-Gaussen, G., 1989. Local, proximal and distal Saharan dusts: characterization and contribution to the sedimentation. In Paleoclimatology and Paleometeorology: Modern and Past Patterns of Global Atmospheric Transport (pp. 339-358). Springer Netherlands.

Csavina, J., Field, J., Taylor, M.P., Gao, S., Landázuri, A., Betterton, E.A., Sáez, A.E., 2012. A review on the importance of metals and metalloids in atmospheric dust and aerosol from mining operations. Sci. Total Environ. 433, 58-73.

Dai, A., 2010. Drought under global warming: a review. WIREs Clim. Change 2, 45-65.

Das, T.M., 1988. Effects of deposition of dust particles on leaves of crop plants on screening of solar illumination and associated physiological processes. Environ. Pollut. 53(1-4), 421-422.

Davis, B., Condra, G., 1989. The on-site costs of wind erosion on farms in New Mexico. J. Soil Water Conserv. 44, 339-343.

de Longueville, F., Ozer, P., Doumbia, S., Henry, S., 2013. Desert dust impacts on human health: An alarming worldwide reality and a need for studies in West Africa. Int. J. Biometeorol. 57(1), 119.10.1007/s00484-012-0541-y.

Deetz, K., Klose, M., Kirchner, I., Cubasch, U., 2016. Numerical simulation of a dust event in northeastern Germany with a new dust emission scheme in COSMO-ART. Atmos. Environ.126, 8797.

Derbyshire, E., Meng, X., Kemp, R.A., 1998. Provenance, transport and characteristics of modern aeolian dust in western Gansu Province, China, and interpretation of the Quaternary loess record. J. Arid Environ. 39(3), 497-516.

Dia, A., Chauvel, C., Bulourde, M., Gérard, M., 2006. Eolian contribution to soils on Mount Cameroon: Isotopic and trace element records. Chem. Geol. 226(3), 232-252.

Ekhtesasi, M.R., Sepehr, A. 2009. Investigation of wind erosion process for estimation, prevention, and control of DSS in Yazd-Ardakan plain. Environ. Model. Assess. 159(1-4), 267-280.

Engelbrecht, J.P., McDonald, E.V., Gillies, J.A., Jayanty, R.K.M., Casuccio, G., Gertler, A.W., 2009. Characterizing mineral dusts and other aerosols from the Middle East—part 1: ambient sampling. Inhal. Toxicol. 21(4), 297-326.

Evan, A.T., Flamant, C., Fiedler, S., Doherty, O., 2014. An analysis of aeolian dust in climate models. Geophys. Res. Lett. 41(16), 5996-6001.

Farmer, A.M., 1993. The effects of dust on vegetation - a review. Environ. Pollut. 79(1), 63-75.

Franzén, L.G., Hjelmroos, M., Kållberg, P., Brorström-Lunden, E., Juntto, S., Savolainen, A.L., 1994. The 'yellow snow episode' of northern Fennoscandia, march 1991-A case study of long-distance transport of soil, pollen and stable organic compounds. Atmos. Environ. 28(22), 3587-3604.

Fuzzi, S., Baltensperger, U., Carslaw, K., Decesari, S., Denier Van Der Gon, H., Facchini, M.C., Nemitz, E., 2015. Particulate matter, air quality and climate: lessons learned and future needs. Atmos. Chem. Phys. 15(14), 8217-8299.

Ganor, E., Osetinsky, I., Stupp, A., Alpert, P. (2010). Increasing trend of African dust, over 49 years, in the eastern Mediterranean. J. Geophys. Res.-Atmos. 115(D7).

Garrison, V.H., Foreman, W.T., Genualdi, S., Griffin, D.W., Kellogg, C.A., Majewski, M.S., Mohammed, A., Ramsubhag, A., Shinn, E.A., Simonich, S.L., Smith, G.W., 2006. Saharan dust - a 
684

685

686

687

688

689

690

691

692

693

694

695

696

697

carrier of persistent organic pollutants, metals and microbes to the Caribbean? Rev. Biol. Trop. 54 (Suppl. 3), 9-21.

Ghasem, A., Shamsipour, A., Miri, M., Safarrad, T. 2012. Synoptic and remote sensing analysis of dust events in southwestern Iran. Nat. Hazards 64(2), 1625-1638.

Giannadaki, D., Pozzer, A., Lelieveld, J., 2014. Modeled global effects of airborne desert dust on air quality and premature mortality. Atmos. Chem. Phys. 14(2), 957-968.

Ginoux, P., Prospero, J. M., Gill, T. E., Hsu, N. C., Zhao, M., 2012. Global-scale attribution of anthropogenic and natural dust sources and their emission rates based on MODIS Deep Blue aerosol products. Rev. Geophys. 50(3).

Gonzalez-Martin, C., Teigell-Perez, N., Valladares, B., Griffin, D.W. 2014. The global dispersion of pathogenic microorganisms by dust storms and its relevance to agriculture. Adv. Agron. 127, 1-41.

Goudie, A.S., 2014. Desert dust and human health disorders. Environ. Int. 63, 101-113.

Goudie, A.S., Middleton, N.J., 1992. The changing frequency of dust storms through time. Clim. Chang. 20(3), 197-225.

Goudie A.S., Middleton N.J. 2006. Desert dust in the global system. Heidelberg: Springer Verlag.

Griffin, D. W. 2007. Atmospheric movement of microorganisms in clouds of desert dust and implications for human health. Clinical microbiology reviews 20(3), 459-477.

Grousset, F.E., Ginoux, P., Bory, A., Biscaye, P.E. 2003. Case study of a Chinese dust plume reaching the French Alps. Geophys. Res. Lett. 30(6).

Hamed, A., Tabakoff, W.C., Wenglarz, R.V., 2006. Erosion and deposition in turbomachinery. J. Propul. Power 22(2), 350-360.

Hector, R.F., Laniado-Laborin, R., 2005. Coccidioidomycosis - a fungal disease of the Americas. PLoS Medicine 2 (1), e2.

Hoffmann, C., Funk, R., Wieland, R., Li, Y. and Sommer, M., 2008. Effects of grazing and topography on dust flux and deposition in the Xilingele grassland, Inner Mongolia. J. Arid Environ. 72(5), 792807.

Holyoak, A.L., Aitken, P.J., Elcock, M. S. 2011. Australian dust storm: impact on a statewide air medical retrieval service. Air medical journal 30(6), 322-327.

Hsu, N.C., Gautam, R., Sayer, A.M., Bettenhausen, C., Li, C., Jeong, M.J., Tsay, S.C., Holben, B.N., 2012. Global and regional trends of aerosol optical depth over land and ocean using SeaWiFS measurements from 1997 to 2010. Atmos. Chem. Phys, 12, pp.8037-8053.

Husar R.B., Tratt DM, Schichtel BA, Falke SR, Li F, Jaffe D, Gasso S, Gill T, Laulainen NS, Lu F, Reheis MC. 2001. Asian dust events of April 1998. J. Geophys. Res.-Atmos. 106(D16):18317-30.

Huszar, P.C., Piper, S.L., 1986. Estimating the off-site costs of wind erosion in New Mexico. J. Soil Water Conserv. 41, 414-416.

Idso, S. B. 1976. Dust storms. Sci. Am. 235, 108-115.

Indoitu, R., Orlovsky, L., Orlovsky, N. 2012. Dust storms in Central Asia: spatial and temporal variations. Journal of Arid Environments, 85, 62-70.

IPCC, 2012. Managing the risks of extreme events and disasters to advance climate change adaptation. In: Field, C.B., Barros, V., Stocker, T.F., Qin, D., Dokken, D.J., Ebi, K.L., Mastrandrea, M.D., Mach, K.J., Plattner, G.-K., Allen, S.K., Tignor, M.,Midgley, P.M. (Eds.), A special report of Working Groups I and II of the Intergovernmental Panel on Climate Change. Cambridge University Press, Cambridge UK, and New York USA.

Issanova G, Abuduwaili J, Galayeva O, Semenov O, Bazarbayeva T 2015. Aeolian transportation of sand and dust in the Aral Sea region. Int. J. Environ. Sci. Technol. 12(10):3213-3224

Jeong, D.Y., 2008. Socio-economic costs from yellow dust damages in South Korea. Korean Social Science Journal, XXXV No. 2, 1-29.

Johnson, M.S., Meskhidze, N., Solmon, F., Gass’o, S., Chuang, P.Y., Gaiero, D.M., Yantosca, R.M., Wu, S., Wang, Y., Carouge, C., 2010. Modeling dust and soluble iron deposition to the South Atlantic Ocean. J. Geophys. Res. 115, D15202, doi:10.1029/2009JD013311. 
Jorquera, H., Borzutzky, A., Hoyos-Bachiloglu, R., García, A., 2015. Association of Kawasaki disease with tropospheric winds in Central Chile: Is wind-borne desert dust a risk factor? Environ. Int. 78, 32-38.

Jugder, D., Shinoda, M., Sugimoto, N., Matsui, I., Nishikawa, M., Park, S.U., Chun, Y-S. Park, M.S. 2011. Spatial and temporal variations of dust concentrations in the Gobi Desert of Mongolia. Glob. Planet. Change, 78(1), 14-22.

Jusot, J.F., Neill, D.R., Waters, E.M., Bangert, M., Collins, M., Moreno, L.B., Lawan, K.G., Moussa, M.M., Dearing, E., Everett, D.B., Collard, J.M., 2016. Airborne dust and high temperatures are risk factors for invasive bacterial disease. J Allergy Clin. Immunol.

Kaly, F., Marticorena, B., Chatenet, B., Rajot, J.L., Janicot, S., Niang, A., Yahi, H., Thiria, S., Maman, A., Zakou, A. and Coulibaly, B.S., 2015. Variability of mineral dust concentrations over West Africa monitored by the Sahelian Dust Transect. Atmos. Res. 164, pp.226-241.

Kang, G.G., Chu, J.M., Jeong, H.S. Han, H. J., Yoo, N.M., 2004. An analysis of the damage from yellow dust in Northeastern Asia and regional cooperation strategy for reducing damage. Seoul: Korea Environment Institute.

Kapp, P., Pullen, A., Pelletier, J.D., Russell, J., Goodman, P., Cai, F., 2015. From dust to dust: Quaternary wind erosion of the Mu Us Desert and Loess Plateau, China. Geology, 43(9), 835-838.

Karanasiou A, Moreno N, Moreno T, Viana M, de Leeuw F, Querol X. 2012. Health effects from Sahara dust episodes in Europe: literature review and research gaps. Environ. Int. 47:107-14.

Kashima S, Yorifuji T, Bae S, Honda Y, Lim YH, Hong YC 2016. Asian dust effect on cause-specific mortality in five cities across South Korea and Japan. Atmos. Environ. 128: 20-27

Kaskaoutis, D.G., Kambezidis, H.D., Nastos, P. T., Kosmopoulos, P.G. 2008. Study on an intense dust storm over Greece. Atmos. Environ. 42(29), 6884-6896.

Kellogg, C.A., Griffin, D.W. 2006. Aerobiology and the global transport of desert dust. Trends Ecol. Evolut. 21(11), 638-644.

Kim J., 2008. Transport routes and source regions of Asian dust observed in Korea during the past 40 years (1965-2004). Atmos. Environ. 42(19), 4778-4789.

Kim, K.H., Jahan, S.A., Kabir, E., 2013. A review on human health perspective of air pollution with respect to allergies and asthma. Environment international 59, 41-52.

Kim, S.W., Yoon, S.C., Kim, J.Y., Kang, J.Y., Sugimoto, N., 2010. Asian dust event observed in Seoul, Korea, during 29-31 May 2008: analysis of transport and vertical distribution of dust particles from lidar and surface measurements. Sci. Total Environ. 408, 1707-1718.

Kirkland, T.N., Fierer, J., 1996. Coccidioidomycosis: a reemerging infectious disease. Emerg. Infect. Diseases, 2(3), 192.

Kok, J.F., Renno, N.O., 2006. Enhancement of the emission of mineral dust aerosols by electric forces. Geophys. Res. Lett. 33(19).

Korea Meteorological Administration, 2016. Asian dust warning system. http://web.kma.go.kr/eng/weather/asiandust/intro.jsp (accessed 12.10.16).

Kutuzov, S., Shahgedanova, M., Mikhalenko, V., Ginot, P., Lavrentiev, I., Kemp, S. 2013. Highresolution provenance of desert dust deposited on Mt. Elbrus, Caucasus in 2009-2012 using snow pit and firn core records. The Cryosphere 7, 1481-1498.

Larney, F.J., Bullock, M.S., Janzen, H.H., Ellert, B.H., Olson, E.C., 1998. Wind erosion effects on nutrient redistribution and soil productivity. J. Soil Water Conserv. 53(2), 133-140.

Lary, D.J., Faruque, F.S., Malakar, N., Moore, A., Roscoe, B., Adams, Z.L., Eggelston, Y., 2014. Estimating the global abundance of ground level presence of particulate matter (PM2.5). Geospat. Health 8(3), 611-630.

Lee J.W., Lee, K.K., 2013. Effects of Asian dust events on daily asthma patients in Seoul, Korea. Meteorol Appl http://dx.doi.org/10.1002/met.1351.

Lee, J.A., Gill, T.E., 2015. Multiple causes of wind erosion in the Dust Bowl. Aeolian Res. 19, 15-36. 
Leys, J.F., Heidenreich, S.K., Strong, C.L., McTainsh, G.H., Quigley, S., 2011. PM 10 concentrations and mass transport during "Red Dawn"-Sydney 23 September 2009. Aeolian Res. 3(3), 327-342.

Lin, T.H., 2001. Long-range transport of yellow sand to Taiwan in Spring 2000: observed evidence and simulation. Atmos. Environ. 35, 5873-5882.

Liu Q, LiuY, Yin J, Zhang M, Zhang T., 2014. Chemical characteristics and source apportionment of PM 10 during Asian dust storm and non-dust storm days in Beijing. Atmos. Environ. 91, 85-94.

Mahowald, N., Kohfeld, K., Hansson, M., Balkanski, Y., Harrison, S.P., Prentice, I.C., Schulz, M. and Rodhe, H., 1999. Dust sources and deposition during the last glacial maximum and current climate: A comparison of model results with paleodata from ice cores and marine sediments. J. Geophys. Res.-Atmos. 104(D13), pp.15895-15916.

Maliszewski, P.J., Larson, E.K., Perrings, C., 2012. Environmental determinants of unscheduled residential outages in the electrical power distribution of Phoenix, Arizona. Reliab. Eng. Syst. Safe. 99, 161-171.

Mamouri, R.-E., Nisantzi, A., Ansmann, A., Hadjimitsis, D.G., 2016. Extreme dust storm over the eastern Mediterranean in September 2015: Lidar vertical profiling of desert dust at Limassol, Cyprus. Atmos. Chem. Phys. Discuss., doi:10.5194/acp-2016-354.

Martinelli, N., Olivieri, O., Girelli, D., 2013. Air particulate matter and cardiovascular disease: a narrative review. Eur. J. Intern. Med. 24(4), 295-302.

Masson, O., Piga, D., Gurriaran, R., D'Amico, D., 2010. Impact of an exceptional Saharan dust outbreak in France: PM 10 and artificial radionuclides concentrations in air and in dust deposit. Atmospheric Environment, 44(20), 2478-2486.

McKendry, I. G., Hacker, J. P., Stull, R., Sakiyama, S., Mignacca, D., Reid, K. 2001. Long-range transport of Asian dust to the lower Fraser Valley, British Columbia, Canada. J. Geophys. Res. Atmos. 106(18), 2-4.

McLeman RA, Dupre J, Ford LB, Ford J, Gajewski K, Marchildon G., 2014. What we learned from the Dust Bowl: lessons in science, policy, and adaptation. Popul. Environ. 35(4): 417-440

McTainsh, G.H., Walker, P.H., 1982. Nature and distribution of Harmattan dust. Z. Geomorphol. 26(4), 417-435.

Meibodi, A. E., Abdoli, G., Taklif, A., Morshedi, B. 2015. Economic modeling of the regional polices to combat dust phenomenon by using game theory. Procedia Economics and Finance 24, 409-418.

Menéndez, I., Diaz-Hernandez, J. L., Mangas, J., Alonso, I., Sanchez-Soto, P. J. 2007. Airborne dust accumulation and soil development in the North-East sector of Gran Canaria (Canary Islands, Spain). J. Arid Environ. 71(1), 57-81.

Middleton, N.J., 1985. Effect of drought on dust production in the Sahel. Nature 316, 431-434.

Middleton, N.J., 1986. A geography of dust storms in South- west Asia. J. Climatol., 6(2), 183-196.

Middleton, N., 2016. Rangeland management and climate hazards in drylands: dust storms, desertification and the overgrazing debate. Nat. Hazards, 1-14.

Middleton, N.J., Sternberg, T., 2013. Climate hazards in drylands: a review. Earth Sci. Rev. 126, 48-57.

Miller R.L., Tegen I., Perlwitz J., 2004. Surface radiative forcing by soil dust aerosols and the hydrologic cycle. J. Geophys. Res. 109:D04203. doi:10.1029/2003JD004085

Miri, A., Ahmadi, H., Ekhtesasi, M. R., Panjehkeh, N., Ghanbari, A., 2009. Environmental and socioeconomic impacts of dust storms in Sistan Region, Iran. Int. J. Environ. Stud. 66(3), 343-355.

Moore, P.S., 1992. Meningococcal meningitis in sub-Saharan Africa: a model for the epidemic process. Clin. Infect. Dis. 14(2), 515-525.

Moulin, C., Lambert, C.E., Dulac, F., Dayan, U., 1997. Control of atmospheric export of dust from North Africa by the North Atlantic Oscillation. Nature 387(6634), 691.

Mueller, J.E., Yaro, S., Madec, Y., Somda, P.K., Idohou, R.S., Njanpop Lafourcade, B.M., Drabo, A., Tarnagda, Z., Sangaré, L., Traoré, Y., Fontanet, A., 2008. Association of respiratory tract infection symptoms and air humidity with meningococcal carriage in Burkina Faso. Trop. Med. Int. Health 13(12), 1543-1552. 
Muhs, D.R., Budahn, J.R., Prospero, J.M., Carey, S.N., 2007 Geochemical evidence for African dust inputs to soils of western Atlantic islands: Barbados, the Bahamas and Florida, J. Geophys. Res., 112, F02009, doi:10.1029/2005JF000445

Nativ, R., Adar, E., Dahan, O., Nissim, I., 1997. Water salinization in arid regions-observations from the Negev desert, Israel. J. Hydrol. 196(1), 271-296.

Noinaj, N., Easley, N.C., Oke, M., Mizuno, N., Gumbart, J., Boura, E., Evans, R.W., 2012. Structural basis for iron piracy by pathogenic Neisseria. Nature 483(7387), 53-58.

Nordstrom, K.F., Hotta, S., 2004. Wind erosion from cropland in the USA: a review of problems, solutions and prospects. Geoderma 121(3), 157-167.

Notaro, M., Yu, Y., Kalashnikova, O.V., 2015. Regime shift in Arabian dust activity, triggered by persistent Fertile Crescent drought. J. Geophys. Res.-Atmos. 120(19).

Park, S.U., In, H.J., 2003. Parameterization of dust emission for the simulation of the yellow sand (Asian dust) event observed in March 2002 in Korea. J. Geophys. Res.-Atmos. 108(D19).

Pimentel, D., Harvey, C., Resosudarmo, P., Sinclair, K., Kurz, D., McNair, M., Crist, S., Shpritz, L., Fitton, L., Saffouri, R. Blair, R., 1995. Environmental and economic costs of soil erosion and conservation benefits. Science-AAAS-Weekly Paper Edition, 267(5201), 1117-1122.

Pio, C.A., Cardoso, J.G., Cerqueira, M.A., Calvo, A., Nunes, T.V., Alves, C.A., Custódio, D., Almeida, S.M., Almeida-Silva, M. 2014. Seasonal variability of aerosol concentration and size distribution in Cape Verde using a continuous aerosol optical spectrometer. Frontiers in Environmental Science 2, 15.

Prospero, J.M., 1999. Long-term measurements of the transport of African mineral dust to the southwestern United States: implications for regional air quality. J. Geophys. Res. 104D 15917-27

Prospero J.M., Ginoux P, Torres O, Nicholson SE, Gill TE, 2002. Environmental characterization of global sources of atmospheric soil dust identified with the NIMBUS-7 TOMS absorbing aerosol product. Rev Geophys 40(1)

Prospero, J.M., Bullard, J.E., Hodgkins, R., 2012. High-latitude dust over the North Atlantic: inputs from Icelandic proglacial dust storms. Science 335(6072), 1078-1082.

Prospero, J.M., Collard, F.X., Molinié, J., Jeannot, A., 2014. Characterizing the annual cycle of African dust transport to the Caribbean Basin and South America and its impact on the environment and air quality. Glob. Biogeochem. Cycles 28(7), 757-773.

Raman, A., Arellano, A.F., Brost, J.J., 2014. Revisiting haboobs in the southwestern United States: An observational case study of the 5 July 2011 Phoenix dust storm. Atmos. Environ. 89, 179-188.

Rashki, A., Kaskaoutis, D.G., Goudie, A.S., Kahn, R.A., 2013. Dryness of ephemeral lakes and consequences for dust activity: the case of the Hamoun drainage basin, southeastern Iran. Sci. Total Environ. 463, 552-564.

Reid, S., MacDonald, C., Alrick, D., Veneziano, D., Koon, L., Pryor, D., Ginn, D., Kresich, D. Tait, T., 2016. Improving the Communication of Safety Information for Windblown Dust Events. In Transportation Research Board 95th Annual Meeting (No. 16-1546).

Remy, G., 1990. Les fondements écologiques de la «ceinture» de la méningite cérébro-spinale en Afrique Sud-saharienne. Climat et santé 3, 7-21.

Reynolds, R.L., Yount, J.C., Reheis, M., Goldstein, H., Chavez, P., Fulton, R., Whitney, J., Fuller, C., Forester, R.M., 2007. Dust emission from wet and dry playas in the Mojave Desert, USA. Earth Surf. Process. Landf. 32(12), 1811-1827.

Riksen, M.J.P.M., De Graaff, J., 2001. On-site and off-site effects of wind erosion on European light soils. Land Degrad. Dev. 12(1), 1-11.

Rodo, X., Curcoll, R., Robinson, M., Ballester, J., Burns, J.C., Cayan, D.R., Lipkin, W.I.,Williams, B.L., Couto-Rodriguez, M., Nakamura, Y., Uehara, R., Tanimoto, H., Morgui, J.A., 2014. Tropospheric winds from northeastern China carry the etiologic agent of Kawasaki disease from its source to Japan. Proc. Natl. Acad. Sci. U. S. A. 111, 7952-7957.

Rutherford S, Clark E, McTainsh GH, Simpson R, Mitchell C., 1999. Characteristics of rural dust events shown to impact on asthma severity in Brisbane, Australia. Int J Biometeorol;42:217-25. 
Safriel, U., Adeel, Z., Niemeijer, D., Puigdefabregas, J., White, R., Lal, R., Winslow, M., Ziedler, J., Prince, S., Archer, E., King, C., 2005. Chapter 22: dryland systems. Millennium Ecosystem Assessment. Ecosystems and Human well-being. World Resources Institute, Washington DC, pp. 623-662.

Saleh, I.M., Abuhdima, E.M., 2011. Effect of sand and dust storms on microwave propagation signals in southern Libya. J. of Energy and Power Engineering 5, 1199-1204.

Sandstrom, T., Forsberg, B., 2008. Desert dust: an unrecognized source of dangerous air pollution? Epidemiology, 19(6), 808-809.

Sarver, T., Al-Qaraghuli, A., Kazmerski, L.L., 2013. A comprehensive review of the impact of dust on the use of solar energy: History, investigations, results, literature, and mitigation approaches. Renew. Sustainable Energy Rev. 22, 698-733.

Schenker, M., 2000. Exposures and health effects from inorganic agricultural dusts. Environ. Health Perspect. 108(Suppl 4), p.661.

Shao, Y., Wyrwoll, K.H., Chappell, A., Huang, J., Lin, Z., McTainsh, G.H., Yoon, S., 2011. Dust cycle: An emerging core theme in Earth system science. Aeolian Res. 2(4), 181-204.

Shinoda M., Gillies J.A., Mikami M., Shao Y., 2011. Temperate grasslands as a dust source: knowledge, uncertainties, and challenges. Aeolian Res. 3(3), 271-293.

Simonson, R.W., 1995. Airborne dust and its significance to soils. Geoderma 65(1), 1-43.

Singer A, Ganor E, Dultz S, Fischer, W., 2003. Dust deposition over the Dead Sea. J. Arid Environ. 53:41-51.

Skonieczny, C., Bory, A., Bout- Roumazeilles, V., Abouchami, W., Galer, S.J.G., Crosta, X., Stuut, J.B., Meyer, I., Chiapello, I., Podvin, T. and Chatenet, B., 2011. The 7-13 March 2006 major Saharan outbreak: Multiproxy characterization of mineral dust deposited on the West African margin. J. Geophys. Res.-Atmos. 116(D18).

Smith, J.L., Lee, K., 2003. Soil as a source of dust and implications for human health. Adv. Agron. 80, 1-32.

Soukup, D., Buck, B., Goossens, D., Ulery, A., McLaurin, B.T., Baron, D. and Teng, Y., 2012. Arsenic concentrations in dust emissions from wind erosion and off-road vehicles in the Nellis Dunes Recreational Area, Nevada, USA. Aeolian Res. 5, 77-89.

Sprigg, W.A., 2016. Dust storms, human health and a global early warning system. In Extreme Weather, Health, and Communities (pp. 59-87). Springer International Publishing.

Sprigg, W.A., Nickovic, S., Galgiani, J.N., Pejanovic, G., Petkovic, S., Vujadinovic, M., Vukovic, A., Dacic, M., DiBiase, S., Prasad, A., El-Askary, H., 2014. Regional dust storm modeling for health services: the case of valley fever. Aeolian Res. 14, 53-73.

Stout, J.E., Warren, A., Gill, T.E., 2009. Publication trends in aeolian research: An analysis of the Bibliography of Aeolian Research. Geomorphology 105(1), 6-17.

Sugimoto, N., Hara, Y., Shimizu, A., Nishizawa, T., Matsui, I., Nishikawa, M., 2013. Analysis of dust events in 2008 and 2009 using the lidar network, surface observations and the CFORS model. AsiaPac. J. Atmos. Sci. 49(1), 27-39.

Swap, R., Garstang, M., Greco, S., Talbot, R., Kållberg, P., 1992. Saharan dust in the Amazon Basin. Tellus B 44(2), 133-149.

Tegen I., Lacis A., Fung I., 1996. The influence of mineral aerosols from disturbed soils on the global radiation budget. Nature 380: 419-22

Terradellas, E., 2015. Barcelona dust forecast center (WMO Regional Specialized Meteorological Center with activity specialization on Atmospheric Sand and Dust Forecast) Activity Report 2015 Enric Terradellas (AEMET) and Sara Basart (BSC-CNS).

Thalib, L., Al-Taiar, A., 2012. Dust storms and the risk of asthma admissions to hospitals in Kuwait. Sci. Total Environ. 433, 347-351.

Thomas, C.S., 1987. The Iranian hostage rescue attempt. Army War College, Carlisle Barracks, PA. 
Thomson, M.C., Jeanne, I., Djingarey, M., 2009. Dust and epidemic meningitis in the Sahel: a public health and operational research perspective. In IOP conference series: Earth and environmental science (Vol. 7, No. 1, p. 012017). IOP Publishing.

Tozer, P., Leys, J. 2013. Dust storms-what do they really cost? Rangeland J. 35(2), 131-142.

UNCCD (United Nations Convention to Combat Desertification), 2005. Regional Master Plan for the Prevention and Control of Dust and Sandstorms in Northeast Asia. Secretariat of UNCCD, Beijing, China.

Uno, I., Eguchi, K., Yumimoto, K., Takemura, T., Shimizu, A., Uematsu, M., Sugimoto, N., 2009. Asian dust transported one full circuit around the globe. Nat. Geosci. 2(8), 557-560.

Vanderstraeten, P., Lénelle, Y., Meurrens, A., Carati, D., Brenig, L., Delcloo, A., Zaady, E., 2008. Dust storm originate from Sahara covering Western Europe: a case study. Atmos. Environ. 42(21), 54895493.

Viglizzo, E.F., Frank, F.C., 2006. Ecological interactions, feedbacks, thresholds and collapses in the Argentine Pampas in response to climate and farming during the last century. Quat. Int. 158, 122126.

Washington, R., Todd, M., Middleton, N.J., Goudie, A.S., 2003. Dust-storm source areas determined by the total ozone monitoring spectrometer and surface observations. Ann. Assoc. Am. Geogr. 93(2), 297-313.

Weinzierl, B., Sauer, D., Minikin, A., Reitebuch, O., Dahlkötter, F., Mayer, B., Emde, C., Tegen, I., Gasteiger, J., Petzold, A., Veira, A., 2012. On the visibility of airborne volcanic ash and mineral dust from the pilot's perspective in flight. Phys. Chem. Earth (A/B/C) 45, 87-102.

WHO (World Health Organization), 2006. WHO Air quality guidelines for particulate matter, ozone, nitrogen dioxide and sulfur dioxide, Global update 2005. Summary of risk assessment. Geneva, WHO.

Williams, P., Young, M., 1999. Costing Dust: How Much Does Wind Erosion Cost the People of South Australia? CSIRO Land and Water, Adelaide (36 pp.).

Worster, D., 1979. Dust bowl: the southern high plains in the 1930s. New York, Oxford University Press.

Yarragunta, Y., Srivastava, S., 2016. Effects of South Asian dust storm on air quality over the capital city of India. Proc. SPIE 9876, Remote Sensing of the Atmosphere, Clouds, and Precipitation VI, 98762C (May 6, 2016); doi:10.1117/12.2223548.

Yumimoto, K., Uno, I., Sugimoto, N., Shimizu, A., Liu, Z., 2008. Adjoint inversion modeling of Asian dust emission using lidar observations. Atmos. Chem. Phys. European Geosciences Union 8 (11), 2869-2884.

Zobeck T.M., Fryrear, D.W., Pettit, R.D., 1989. Management effects on wind eroded sediment and plant nutrients. J. Soil Water Conserv. 44: 31: 519-532. 